\title{
Pelatihan Pemanfaatan ICT Untuk Industri Rumahan Kecamatan Kendit Kabupaten Situbondo
}

\author{
Ginanjar Abdurrahman \\ Jurusan Teknik Informatika, Universitas Muhammadiyah Jember \\ abdurrahmanginanjar@unmuhjember.ac.id
}

\begin{abstract}
.Kendit is one of the districts in the Situbondo regency. Based on observation, the technological literacy of the community needs to be improved. ICT is currently very much needed, especially for the home industry. To increase technological literacy, it is necessary to provide ICT Utilization Training for the community, especially for the home industry, to facilitate production and promotion. To carry out ICT Training, of course, facilities needed. The survey determined that SMK Negeri 1 Panji was the place for training activities because it had adequate computer laboratory facilities, both from the number of computers and internet connections. This activity was held on 22-23 November 2017. On the first day, introducing the presenters, followed by giving pretest questions to measure the participants' initial knowledge. After the pretest carried out, then the presentation of material on the introduction of ICT in general, the introduction of ICT for the Home Industry, searching for information using the internet, and calculating production costs and selling prices. On the second day, there was an explanation and discussion about marketing products using social media, correspondence, creating business profiles, making promotional slides with PowerPoint, and ending a posttest. From the activity evaluation data, the participants' lowest posttest score is 71, and the highest score of participants is over 90, as many as two people. When compared with the value at the pretest with the highest score of only 76, it can say that there was a significant increase in the value
\end{abstract}

Keywords : Panji, Situbondo, ICT, Home Industry, Kendit

\begin{abstract}
Abstrak
Kendit merupakan salah satu kecamatan di Kabupaten Situbondo. Dari pengamatan yang dilakukan, literasi teknologi informasi masyarakat kecamatan Kendit masih perlu ditingkatkan. ICT saat ini sangat diperlukan, khususnya untuk kepentingan pelaku industri rumahan Untuk meningkatkan literasi teknologi informasi diperlukan "Pelatihan Pemanfaatan ICT bagi masyarakat, khususnya pelaku industri rumahan, untuk mempermudah kegiatan produksi dan promosi. Untuk melaksanakan pelatihan ICT tentunya diperlukan fasilitas pada kegiatan pelatihan.. Dari survey yang dilakukan, ditentukan SMK Negeri 1 Panji sebagai tempat kegiatan dikarenakan instansi ini mempunyai fasilitas laboratorium komputer yang memadai, baik dari jumlah komputer maupun koneksi internet. Kegiatan ini dilaksanakan pada tanggal 22-23 November 2017. Pada hari pertama, diawali dengan perkenalan pemateri, dilanjutkan dengan memberikan soal pretest untuk mengukur pengetahuan awal peserta. Setelah dilaksanakan pretest, selanjutnya pemaparan materi tentang pengenalan ICT secara umum, pengenalan ICT bagi Industri Rumahan, mencari informasi menggunakan internet, serta menghhitung biaya produksi dan harg jual. Pada hari kedua dilaksanakan pemaparan dan diskusi mengenai memasarkan produk menggunakan media sosial, korespondensi surat-menyurat, membuat profil usaha, membuat slide promosi dengan powerpoint, dan diakhiri dengan pengambilan posttest, Dari data hasil evaluasi kegiatan dapat terlihat bahwa dari nilai terendah posttest peserta yakni 71, dan nilai tertinggi peserta ada yang mencapai di atas 90 sebanyak 2 orang. Jika dibandingkan dengan nilai pada pretest dengan nilai tertinggi hanya mencapai 76, dapat dikatakan bahwa terjadi peningkatan nilai yang cukup signifikan.
\end{abstract}

Kata Kunci: Panji, Situbondo, ICT, Industri Rumahan, Kendit

\section{PENDAHULUAN}

Kabupaten Situbondo terdiri dari 17 Kecamatan, yakni: Kecamatan Arjasa, Kecamatan Asembagus, Kecamatan
Banyuglugur, Kecamatan Banyuputih, Kecamatan Besuki, Kecamatan Bungatan, Kecamatan Jangkar, Kecamatan Jatibanteng, Kecamatan Kapongan, Kecamatan Kendit, Kecamatan Mangaran, Kecamatan Mlandingan, Kecamatan

http://comdev.pubmedia.id | Indonesian Journal Publisher | http://idpublishing.org 
Panarukan, Kecamatan Panji, Kecamatan Situbondo, Kecamatan Suboh, dan Kecamatan Sumbermalang (Kemenpan, 2017). Kecamatan Kendit adalah sebuah kecamatan di Kabupaten Situbondo, Jawa Timur. Luas kecamatan ini adalah $114,14 \mathrm{~km}^{2}$. Mayoritas penduduknya bermata pencaharian sebagai petani dan peternak ada juga yang bekerja ke mancanegara terutama Arab Saudi dan Malaysia. Mayoritas penduduknya beragama Islam dan keturunan etnis Madura. Adapun keturunan etnis lainnya, yakni keturunan Arab, Bali dan Tionghoa. Pusat kecamatan terletak di desa Kendit dengan banyak infrastruktur terpusat di Desa Kendit seperti sarana spiritual berupa tempat ibadah, yaitu Masjid Jami’ At Taqwa, kantor kecamatan, kantor koramil, Polsek Kendit, dan alunalun kota, serta lapangan olahraga. Kecamatan Kendit terbagi menjadi 7 desa, yakni desa Kendit, desa Bugeman, desa Tambak Ukir, desa Rajekwesi, desa Kukusan, desa Klatakan, dan Desa Balung. Di sektor ekonomi dan perdagangan hingga saat ini kecamatan Kendit masih belum memiliki pasar, baik pasar tradisional ataupun pasar modern sehingga transaksi jual beli harus dilakukan di luar daerah (Pemerintah Kabupaten Situbondo, 2017) .

Masyarakat kecamatan Kendit sebagian besar penduduknya masih memerlukan peningkatan kompetensi di bidang teknologi informasi. ICT saat ini sangat diperlukan, khususnya untuk kepentingan pelaku industri rumahan. Dalam penyusunan laporan keuangan akan lebih mudah jika menggunakan Microsoft Excel karena dapat menghitung nominal secara langsung, dan tersusun rapi dalam tabel. Disamping itu, pelaku industri rumahan juga dapat memanfaatkan Microsoft Word untuk membuat proposal usaha dan membuat laporan tahunan, sedangkan Microsoft Powerpoint dapat digunakan untuk presentasi profil usaha yang diajukan, berikut produk yang akan dipromosikan dengan interaktif, sehingga menarik konsumen untuk membelinya.

Dari pengamatan yang dilakukan, sebagian sudah mempunyai akun sosial media, akan tetapi dibuatkan oleh kerabat yang mempunyai kompetensi teknologi informasi, sehingga teknis pendaftaran sosial media terkait pendaftaran email sebagai syarat pendaftaran media social belum dikuasai sepenuhnya. Meskipun dari wawancara dengan seorang peserta pelatihan diperoleh data bahwa peserta tersebut sudah menguasai ICT dasar, sudah terbiasa membuat laporan keuangan menggunakan Microsoft excel dan Microsoft word, menyajikan presentasi profil perusahaan dengan menggunakan Microsoft powerpoint, mempromosikan produk dengan menggunakan media sosial (whatsapp, facebook, instagram). Namun demikian, pengetahuan masyarakat mengenai pemanfaatan ICT belum merata. Untuk itulah, diperlukan "Pelatihan Pemanfaatan ICT untuk masyarakat kecamatan
Kendit, khususnya pelaku Industri rumahan”. Hal ini dimaksudkan agar dapat mempermudah kegiatan industry rumahan, baik produksi maupun promosi produk ke masyarakat di lingkungan kecamatan Kendit maupun di luar kecamatan Kendit.

Untuk melaksanakan pelatihan ICT dasar untuk industri rumahan, tentunya diperlukan fasilitas terkait teknis pelaksanaan kegiatan pelatihan. Dalam hal ini seperangkat komputer yang terkoneksi internet. Dari survey yang dilakukan sebelum melaksanakan kegiatan, ditentukan tempat penyelenggaraan kegiatan adalah SMK Negeri 1 Panji. Alasan pemilihan tempat pelatihan di SMK Negeri 1 Panji dikarenakan instansi ini mempunyai fasilitas laboratorium komputer yang memadai, baik dari jumlah komputer maupun koneksi internet.

SMK Negeri 1 Panji terletak di desa Mimbaan, kecamatan Panji, kabupaten Situbondo, Provinsi Jawa Timur. SMK Negeri 1 Panji merupakan SMK Unggulan di Kabupaten Situbondo. Hal ini dapat dilihat dari data DAPODIK DIKDASMEN KEMDIKBUD yang menyatakan bahwa SMK N 1 Panji Terakreditasi A (Direktorat Jenderal Pendidikan Anak Usia Dini, 2017). Disamping itu, dari data penerimaan siswa baru (PSB) SMK tanggal 17 Juni 2017 (SMKN1PANJ, 2017), dapat dilihat bahwa dari 104 siswa yang diterima, 30 siswa berasal dari jalur prestasi, 1 siswa berasal dari jalur bidikmisi, dan 73 siswa berasal dari jalur mitra warga. SMK Negeri 1 Panji membuka 14 kompetensi keahlian yaitu: 1)Otomasti dan Tata Kelola Perkantoran, 2)Perbankan dan Keuangan Mikro, 3)Akuntansi dan Keuangan Lembaga, 4)Bisnis Daring dan Pemasaran, 5)Perhotelan, 6)Tata Boga, 7)Tata Busana, 8)Tata Kecantikan Kulit dan Rambut, 9)Teknik Komputer dan Jaringan, 10)Multimedia, 11)Rekayasa Perangkat Lunak, 12)Agribisnis Pengolahan Hasil Perikanan, 13)Agribisnis Pengolahan Hasil Pertanian, 14)Desain Komunikasi Visual. Disamping itu, sarana dan prasarana di SMK Negeri 1 Panji adalah sebagai berikut: 1)Internet gratis 24/7 Non Stop, 2)12 Laboratorium Komputer Full AC, 3)1 Laboratorium Bahasa, 4)ICT Center, 5)Lapangan Basket, 6)Lapangan Voley, 7)Lapangan Bulutangkis, 8)Aula atau tempat pertemuan, 9)Ruang rapat VIP, 10)Parkir kendaraan luas, 11)Ruang Terbuka Hijau, 12)Bussiness Center (mini market), 13)Fotocopy center, 14)Bank Mini, 15)Bank Mini, 15)Pujasera, dan 16)Kantin (Direktorat Jenderal Pendidikan Anak Usia Dini, 2017)..

Adapun kompetensi yang diharapkan dari kegiatan PKM ini adalah (KPPA, 2017b): Pengenalan ICT Bagi Industri Rumahan, Mencari Informasi Menggunakan Internet, Menghitung Biaya Produksi dan Harga Jual, Memasarkan Produk Menggunakan Media Sosial, Korespondensi-Surat 
DOI : $\underline{10.47134 / \text { comdev.v1i2.8 }}$

Menyurat, dan Membuat Profil Usaha dan Pengajuan Kebutuhan Dana.

\section{METODE}

Tujuan umum pelatihan pemanfaatan ICT dari buku panduan Instruktur ICT untuk industri rumahan adalah untuk memperoleh wawasan baru dan cara pandang dalam mengelola usaha yang mereka jalani dengan memanfaatkan ICT dengan optimal (KPPA, 2017a). Dari tujuan umum tersebut, kemudian diturunkan ke dalam tujuan kegiatan Program Kemitraan Masyarakat (PKM), yakni pelaku industri rumahan kecamaatan Kendit mempunyai pengetahuan dan keterampilan yang memadai mengenai ICT dasar sebagai penunjang kegiatan industri rumahan. Kompetensi yang perlu dikuasai oleh pelaku industri rumahan setidaknya untuk adalah pengoperasian Microsoft Office: Microsoft Word, Microsoft Excel, Microsoft Power Point, email, sosial media (whatsapp, instagram, facebook, dan twitter), mesin pencari (google, yahoo, bing), pengenalan youtube, pengenalan browser: mozila firefox dan Google Chrome.

Kegiatan ini dilaksanakan selama dua hari, yakni pada tanggal 23-24 November 2017. Pada hari pertama, diawali dengan perkenalan pemateri dan ramah tamah sebagai pembuka kegiatan, dilanjutkan dengan memberikan soal pretest untuk mengukur pengetahuan awal peserta. Setelah dilaksanakan pretest, selanjutnya pemaparan materi tentang pengenalan ICT secara umum, pengenalan ICT bagi Industri Rumahan, mencari informasi menggunakan internet, serta menghhitung biaya produksi dan harg jual. Sedangkan pada hari kedua adalah pemaparan dan diskusi materi mengenai memasarkan produk menggunakan media social, korespondensi surat-menyurat, membuat profil usaha, membuat slide promosi dengan powerpoint, dan diakhiri dengan pengambilan posttest, Selengkapnya, kegiatan pengabdian kepada masyarakat ini disajikan dalam Tabel 1.

Tabel 1. Kegiatan Pengabdian Kepada Masyarakat

\begin{tabular}{|l|l|l|}
\hline No. & \multicolumn{1}{|c|}{$\begin{array}{c}\text { Materi \& } \\
\text { Tanggal } \\
\text { pelaksanaan }\end{array}$} & \multicolumn{1}{c|}{ Uraian } \\
\hline & $\begin{array}{l}\text { Pretest } \\
22 \text { November } \\
2017\end{array}$ & $\begin{array}{l}\text { Pretest dilakukan untuk } \\
\text { mengukur kemampuan awal } \\
\text { dari peserta terkait pengetahuan } \\
\text { dasar mengenai ICT }\end{array}$ \\
\hline 1 & $\begin{array}{l}\text { Pengenalan ICT } \\
22 \text { November } \\
2017\end{array}$ & $\begin{array}{l}\text { Perangkat keras } \\
\text { (Hardware) } \\
\text { Perangkat Lunak } \\
\text { (Software) }\end{array}$ \\
\hline
\end{tabular}

\begin{tabular}{|c|c|c|}
\hline No. & $\begin{array}{c}\text { Materi \& } \\
\text { Tanggal } \\
\text { pelaksanaan }\end{array}$ & Uraian \\
\hline & & $\begin{array}{l}\text { - Input/Output } \\
\text { - Tren Peranti Teknologi } \\
\text { Informasi } \\
\text { - Perangkat Nirkabel } \\
\text { (Wireless) } \\
\text { - Perangkat Penyimpanan } \\
\text { Data } \\
\text { - Bidang-bidang yang } \\
\text { memanfaatkan teknologi } \\
\text { komputer: Kesehatan, } \\
\text { Perbankan, Properti, } \\
\text { Keuangan, Perdagangan, } \\
\text { Sosial }\end{array}$ \\
\hline 2. & $\begin{array}{l}\text { Pengenalan ICT } \\
\text { bagi industri } \\
\text { rumahan } \\
22 \text { November } \\
2017\end{array}$ & $\begin{array}{l}\text { - } \text { Pertahanan dan Keamanan } \\
\text { - } \text { online, Taksi online } \\
\text { - } \text { Bidang Kepolisian } \\
\text { Bidang Pendidikan: E- } \\
\text { Journal, E-Learning } \\
\text { - Perbankan: Transfer online, } \\
\text { Internet Banking, SMS } \\
\text { Banking } \\
\text { Bidang Ekonomi: E- } \\
\text { comnerce, Online Shop, } \\
\text { Bitcoin } \\
\text { Bidang Pendidikan: E- } \\
\text { Journal, E-learning, } \\
\text { kemudahan siswa } \\
\text { mengakses informasi dari } \\
\text { website, } \\
\text { Dampak positif dan } \\
\text { dampak negative teknologi } \\
\text { informasi terhadap dunia } \\
\text { pendidikan. }\end{array}$ \\
\hline 3. & $\begin{array}{l}\text { Mencari Informasi } \\
\text { menggunakan } \\
\text { internet } \\
22 \text { November } \\
2017\end{array}$ & $\begin{array}{l}\text { - Memahami dasar-dasar } \\
\text { internet dalam mencari } \\
\text { informasi } \\
\text { - Mengenalkan mesin pencar } \\
\text { (search engine), cara kerja } \\
\text { dan penggunaannya. } \\
\text { - Mencari informasi } \\
\text { mengenai produk industri } \\
\text { rumahan, bahan baku, alat } \\
\text { bantu, competitor desain }\end{array}$ \\
\hline
\end{tabular}


DOI : $\underline{10.47134 / \text { comdev.v1i2.8 }}$

\begin{tabular}{|c|c|c|}
\hline No. & $\begin{array}{c}\text { Materi \& } \\
\text { Tanggal } \\
\text { pelaksanaan }\end{array}$ & Uraian \\
\hline & & $\begin{array}{l}\text { produk, dan pengetahuan } \\
\text { cara produksi. }\end{array}$ \\
\hline 4. & $\begin{array}{l}\text { Menghitung biaya } \\
\text { produksi dan } \\
\text { harga jual } \\
22 \text { November } \\
2017\end{array}$ & 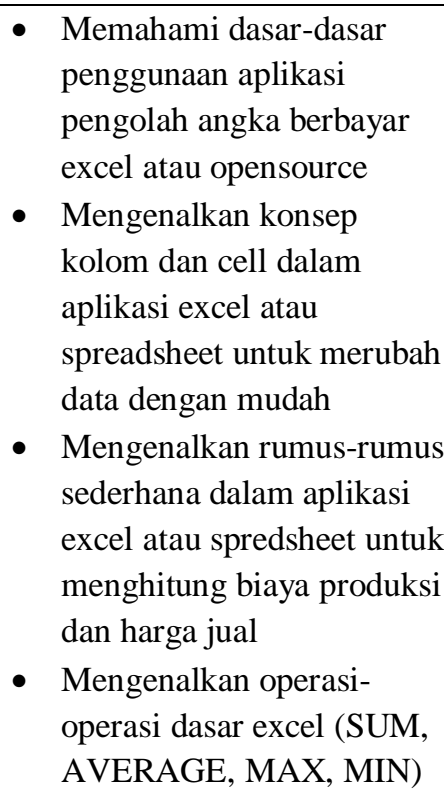 \\
\hline 5. & $\begin{array}{l}\text { Memasarkan } \\
\text { produk } \\
\text { menggunakan } \\
\text { media sosial } \\
23 \text { November } \\
2017\end{array}$ & $\begin{array}{l}\text { - Memahami dasar-dasar } \\
\text { pembuatan e-mail (email) } \\
\text { untuk registrasi media } \\
\text { social } \\
\text { - Mengenalkan media sosial } \\
\text { Facebook, Whatsapp, } \\
\text { Instagram, dan Twitter. } \\
\text { - Mengenalkan aplikasi } \\
\text { Whatsapp untuk } \\
\text { memasarkan produk } \\
\text { Memasarkan Produk } \\
\text { UKM-Industri Rumahan } \\
\text { yang dimiliki melalui } \\
\text { media social }\end{array}$ \\
\hline 6. & $\begin{array}{l}\text { Korespondensi } \\
\text { Surat-Menyurat } \\
23 \text { November } \\
2017\end{array}$ & $\begin{array}{ll}\text { - } & \text { Memahami dasar-dasar } \\
\text { penggunaan email (Gmail) } \\
\text { - } \\
\text { Memahami fitur-fitur } \\
\text { korespondensi surat- } \\
\text { menyurat menggunakan } \\
\text { email (Gmail) } \\
\text { - Mempraktekankan } \\
\text { korespondensi surat- } \\
\text { menyurat menggunakan } \\
\text { email (Gmail) }\end{array}$ \\
\hline 7. & $\begin{array}{l}\text { Membuat Profil } \\
\text { Usaha dan }\end{array}$ & $\begin{array}{l}\text { - Memahami dasar-dasar } \\
\text { Microsoft word }\end{array}$ \\
\hline
\end{tabular}

\begin{tabular}{|l|l|ll|}
\hline No. & \multicolumn{1}{|c|}{$\begin{array}{c}\text { Materi \& } \\
\text { Tanggal } \\
\text { pelaksanaan }\end{array}$} & \multicolumn{1}{c|}{ Uraian } \\
\hline & $\begin{array}{l}\text { Pengajuan } \\
\text { Pinjaman } \\
23 \text { November } \\
2017\end{array}$ & - & $\begin{array}{l}\text { Memahami dasar-dasar } \\
\text { pembuatan profil usaha } \\
\text { Memahami dasar-dasar } \\
\text { kebutuhan dana sederhana }\end{array}$ \\
\hline 8. & $\begin{array}{l}\text { Membuat slide } \\
\text { promosi dengan } \\
\text { powerpoint } \\
23 \text { November } \\
2017\end{array}$ & $\begin{array}{l}\text { - } \\
\text { Mengenal Microsoft } \\
\text { Powerpoint }\end{array}$ \\
& $\begin{array}{l}\text { Mengedit Slide tampilan } \\
\text { normal }\end{array}$ \\
& $\begin{array}{l}\text { Mengatur format teks } \\
\text { - Mengatur tampilan slide } \\
\text { presentasi }\end{array}$ \\
& - $\begin{array}{l}\text { Membuat table, data, dan } \\
\text { grafik } \\
\text { Menjalankan presentasi }\end{array}$ \\
\hline & $\begin{array}{l}\text { Posttest dilaksanakan } \\
\text { untuk mengukur } \\
\text { pemahaman terkait materi } \\
23 \text { November } \\
2017\end{array}$ & \begin{tabular}{l} 
yang telah disampaikan. \\
\hline
\end{tabular} \\
\hline
\end{tabular}

\section{HASIL DAN PEMBAHASAN}

Kegiatan pengabdian kepada masyarakat yang dilaksanakan pada tanggal 22-23 November 2017 dengan sasaran pelaku industri rumahan kecamatan Kendit kabupaten Situbondo berjalan dengan lancar. Hal ini terlihat dari daftar hadir peserta Pelatihan Pemanfaatan ICT untuk Industri Rumahan Kecamatan Kendit Kabupaten Situbondo. Peserta Pelatihan berjumlah 18 orang Ibu rumah tangga. Peserta pelatihan mengikuti pelatihan dengan antusias, hal ini terlihat dari peserta yang menyimak dan mempraktekkan materi yang dipaparkan. Sehingga dapat diindikasikan bahwa para pelaku industri rumahan menyambut positif kegiatan kepada masyarakat yang diselenggarakan.

Hasil evaluasi peserta terkait pemahaman konsep disajikan dalam bentuk nilai dengan skala nilai antara (0-100) terhadap 18 peserta pelatihan. Penilaian dilaksanakan dalam dua tahap, yakni pretest (sebelum penyampaian materi) dan posttest (sesudah penyampaian materi). Hasil pretest disajikan dalam grafik sebagai berikut: 


\section{Pretest Pengetahuan Awal Peserta \\ $100 \quad 55^{76} 45^{53}{ }^{71} 576361_{35}{ }^{55} 433533^{55} 45^{57} 44^{67}$

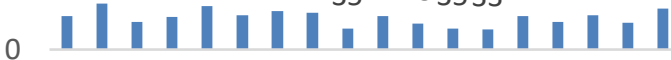 \\ 12334566789101112131415161718 \\ n Nilai}

Gambar 1. Hasil Pretest Peserta

Sedangkan hasil posttest disajikan dengan grafik sebagai berikut:

\section{Posttest Pemahaman Materi Pelatihan}

817682887675717778928482819081858382

100
0

123456789101112131415161718

$$
\text { Nilai }
$$

Gambar 2. Pretest Peserta Pelatihan

Dari data hasil evaluasi tersebut dapat terlihat bahwa pemahaman materi peserta setelah pemberian materi sudah sangat baik jika dibandingkan dengan sebelum pemaparan materi. Hal ini dapat dilihat dari nilai terendah posttest peserta yakni 71, dan nilai tertinggi peserta ada yang mencapai di atas 90 sebanyak 2 orang. Jika dibandingkan dengan nilai pada pretest dengan nilai tertinggi hanya mencapai 76 , dapat dikatakan bahwa terjadi peningkatan nilai yang cukup signifikan.

Dokumentasi kegiatan pengabdian kepada masyarakat disajikan dalam foto-foto kegiatan pada Gambar 3- Gambar 6.

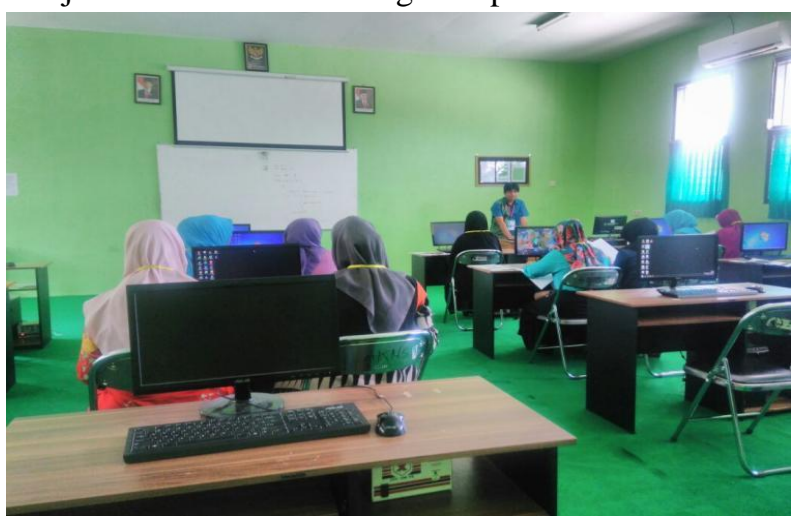

Gambar 3. Pelaksanaan Pretest

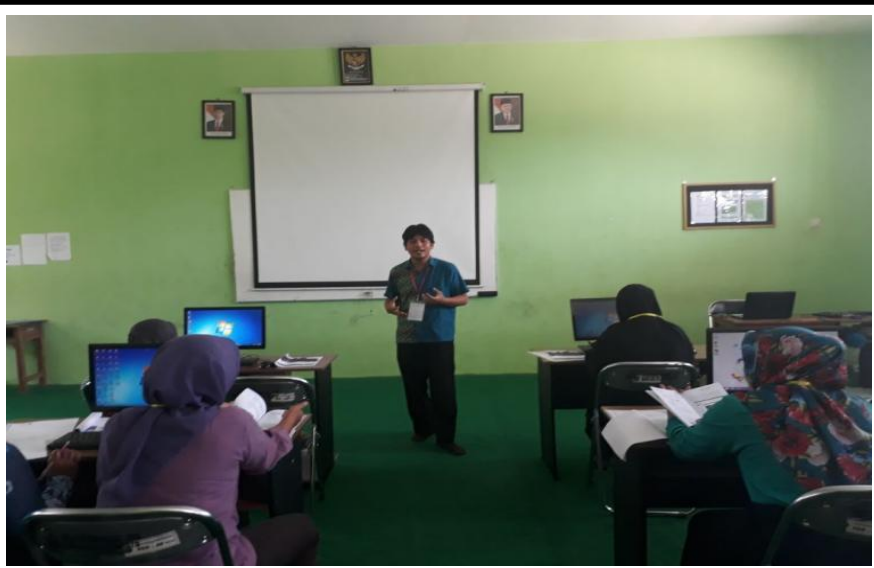

Gambar 4. Penyampaian Materi dan Diskusi

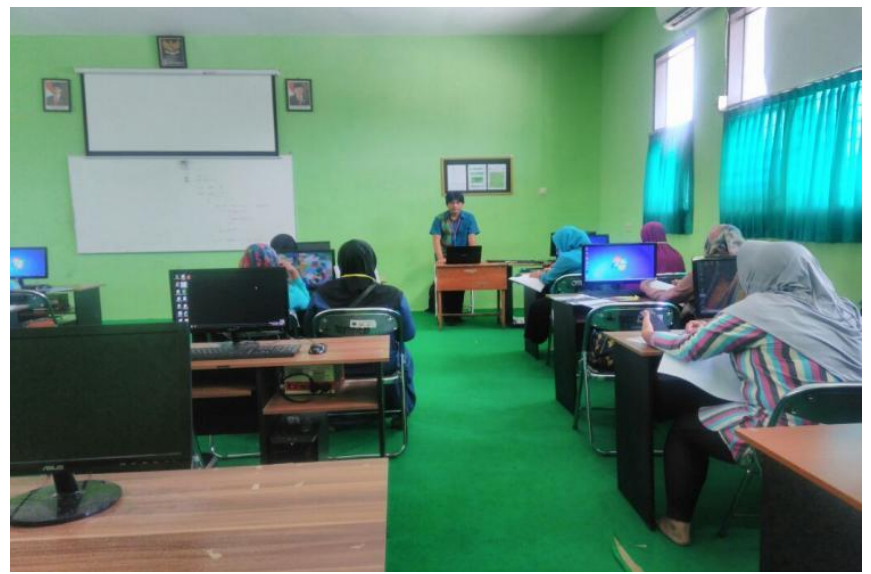

Gambar 5. Pelaksanaan Posttest

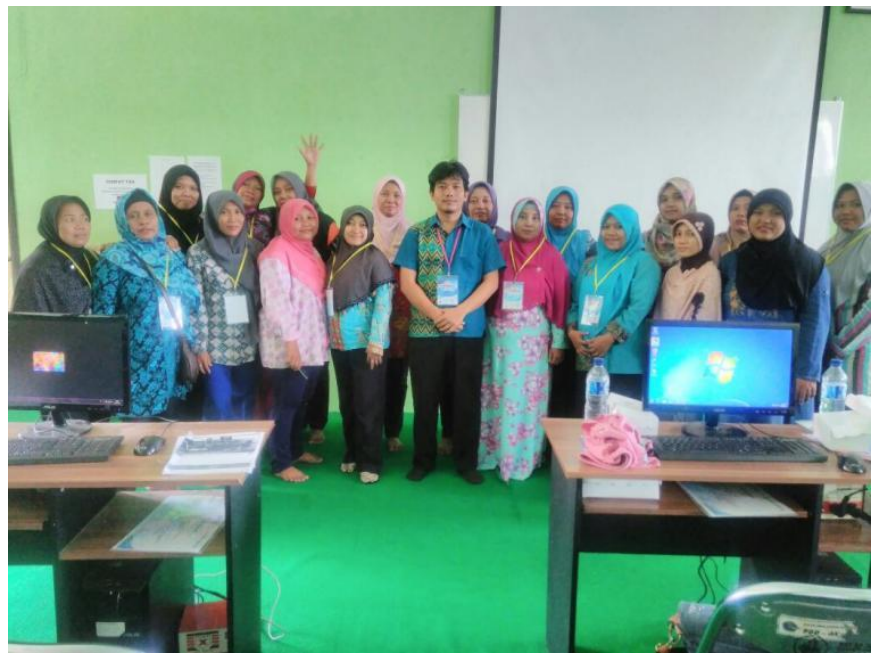

Gambar 6. Foto Bersama setelah acara.

\section{Kendala Pelaksanaan}

Pengabdian kepada masyarakat yang diselenggarakan menghadapi kendala sebagai berikut. 
a. Kemampuan peserta yang beragam, ada yang sudah berpengalaman memanfaatkan ICT dalam menjalankan usaha, sudah terbiasa membuat proposal pengajuan dana dan laporan keuangan menggunakan Microsoft Excel. Namun demikian ada juga yang belum pernah memegang komputer. Dan kebanyakan peserta mempunyai akun email, tetapi dibuatkan kerabat yang menguasai ICT, sehingga terkait teknik pembuatan email belum menguasai dan tidak mengetahui jika untuk mendaftar di media social diperlukan informasi akun email, terkait username dan password.

b. Sebagian peserta sudah usia lanjut sehingga mengalami kesulitan tersendiri untuk penyampaian materi, materi harus sering diulang yang menyebabkan banyak waktu yang tersita.

c. Waktu yang dialokasikan terbatas sehingga ada beberapa materi yang akhirnya dibahas sekilas, bahkan ada materi yang tidak tersampaikan.

d. LCD di tempat kegiatan tidak menyala sehingga pelatihan kurang efektif.

Beberapa komputer tidak dapat dinyalakan, belum terinstal aplikasi yang dibutuhkan untuk pelatihan, dan tidak terkoneksi internet, sehingga ada beberapa peserta yang menggunakan komputer secara bersama-sama

\section{KESIMPULAN}

Kegiatan pengabdian kepada masyarakat dengan judul "Pelatihan Pemanfaatan ICT untuk Industri Rumahan Kecamatan Kendit Kabupaten Situbondo" yang dilaksanakan pada tanggal 22-23 November 2017 dapat disimpulkan sebagai berikut.

a. Dari data hasil evaluasi kegiatan dapat terlihat bahwa pemahaman materi peserta setelah pemberian materi sudah sangat baik jika dibandingkan dengan sebelum pemaparan materi. Hal ini dapat dilihat dari nilai terendah posttest peserta yakni 71 , dan nilai tertinggi peserta ada yang mencapai di atas 90 sebanyak 2 orang. Jika dibandingkan dengan nilai pada pretest dengan nilai tertinggi hanya mencapai 76 , dapat dikatakan bahwa terjadi peningkatan nilai yang cukup signifikan.

b. Motivasi dan rasa ingin tahu yang tinggi untuk belajar akan pengetahuan baru tidak hanya dimiliki oleh generasi muda, peserta pelatihan yang sebagian sudah paruh baya memiliki semangat yang tinggi.

c. Kemampuan peserta yang beragam sangat berpengaruh terhadap pelatihan yang efektifas

d. Pelatihan pemanfaatan ICT ini sangat diperlukan bagi pelaku industri rumahan karena sangat membantu pekerjaan khususnya dalam penyusunan proposal pengajuan usaha, laporan keuangan, serta promosi baik produk maupun usaha yang dilakukan oleh pelaku industri rumahan.

Berdasarkan pelaksanaan pelatihan tersebut, pelaksanaan pengabdian kepada masyarakat yang akan datang sebaiknya,

a. Peserta memiliki kemampuan awal yang sama sehingga materi dapat serentak diajarkan

b. Pelatihan diberikan pada peserta dengan usia produktif

Koordinasi yang lebih efektif antara pelaksana pengabdian baik dengan tempat pelaksanaan kegiatan maupun peserta

\section{UCAPAN TERIMAKASIH}

Penulis menyampaikan terima kasih kepada beberapa pihak yang telah mendukung dalam pelaksanaan kegiatan pengabdian kepada masyarakat ini, khususnya LPPM Universitas Muhammadiyah Jember karena telah memberikan dukungan dana pelaksanaan pengabdian.

\section{DAFTAR PUSTAKA}

Direktorat Jenderal Pendidikan Anak Usia Dini, P. D. dan P. M. (2017). Data Pokok Pendidikan. https://dapo.kemdikbud.go.id/sekolah/ 10DC555EF9560E5823E3

Kemenpan. (2017). Pemerintah Kab. Situbondo. https://sipp.menpan.go.id/pelayanan_publik/wilayah/pemerint ah-provinsi-jawatimur/pemerintah-kab-situbondo

KPPA. (2017a). Buku Panduan Instruktur-Pelatihan Pemanfaatan ICT untuk Industri Rumahan.

KPPA. (2017b). Buku Panduan Peserta-Pelatihan Pemanfaatan ICT untuk Industri Rumahan.

Pemerintah Kabupaten Situbondo. (2017). Profil Kabupaten Situbondo. https://web.situbondokab.go.id/

SMKN1PANJI. (2017). Profil SMK N 1 Panji. http://smkn1panjisit.sch.id/ 